\title{
JNPH
}

Volume 7 No. 1 (April 2019)

(C) The Author(s) 2019

\section{PENGOLAHAN LIMBAH MEDIS MENGGUNAKAN INCINERATOR BIOMASSA RAMAH LINGKUNGAN}

\section{MEDICAL WASTE PROCESSING USING ENVIRONMENTALLY FRIENDLY BIOMASS INCINERATOR}

\author{
ARIE IKHWAN SAPUTRA \\ POLITEKNIK KESEHATAN KEMENTERIAN KESEHATAN BENGKULU, \\ JURUSAN KESEHATAN LINGKUNGAN, \\ JALAN INDRAGIRI NOMOR 3 PADANG HARAPAN BENGKULU \\ Email: keslingpoltek@gmail.com
}

\begin{abstract}
ABSTRAK
Klinik medis maupun Pusat pelayanan Kesehatan Masyarakat sejak dulu sampai sekarang adalah sebagai ujung tombak pelayanan kesehatan di masyarakat, karena Fasilitas pelayanan kesehatan tersebut langsung bersentuhan dengan masyarakat terutama di pedesaan atau masyarakat ekonomi menengah ke bawah. Bentuk pelayanan itu dapat penanganan langsung kepada pasien atau dalam tahap membuka wacana kesadaran masyarakat akan pentingnya kesehatan lingkungan. Pengendalian pencemaran udara pada incinerator ini menggunakan technology After Burner yang berlaku sebagai Second Chamber, sedangkan untuk pengendalian pencemaran udaranya menggunakan Technology Wet Scrubber dengan solvent air. Penelitian ini bertujuan untuk membuat prototype alat incinerator biomassa yang dapat digunakan dalam pengolahan limbah medis. Adapun jenis penelitian ini adalah bersifat eksperimen. Metode penelitian ekperimen diartikan sebagai metode penelitian yang digunakan untuk mencari pengaruh perlakuan tertentu terhadap yang lain dalam kondisi yang terkendali. Penelitian ini bertujuan untuk menganalisis pengaruh jenis Biomassa yang digunakan dalam proses pembakaran limbah medis B3. Dari hasil penelitian dapat disimpulkan pencapaian suhu tertinggi didapat pada jenis biomasa tempurung kelapa yaitu didapatkan suhu puncak $705{ }^{\circ} \mathrm{C}$. Sedangkan efesiensi reduksi/penghancuran tertinggi didapatkan pada variable jenis biomassa tatal kayu/ serbuk gergaji dengan efesiensi penyisihan mencapai $98 \%$.
\end{abstract}

Kata Kunci: Inchinerator, Biomasa, Abu.

\begin{abstract}
Medical clinics and Public Health Service Centers have been the spearhead of health services in the community since the health service facilities were directly in contact with the community, especially in the rural or middle to lower economic communities. The form of service can be handled directly to the patient or in the stage of opening the discourse of public awareness of the importance of environmental health. Air pollution control in this incinerator uses technology After Burner which applies as Second Chamber, while for air pollution control uses Technology Wet Scrubber with water solvent. This study aims to make a prototype of a biomass incinerator that can be used in processing medical waste. The type of this research is experimental.
\end{abstract}


Experimental research methods are defined as research methods used to find the effect of certain treatments on others in controlled conditions. This study aims to analyze the effect of the type of biomass used in the process of burning B3 medical waste. From the results of the study it can be concluded that the highest temperature attainment was found in the type of coconut shell biomass which was obtained at peak temperature of $705 \mathrm{oC}$. While the highest reduction / destruction efficiency was obtained in the variable type of wood / sawdust biomass with the efficiency of elimination reaching $98 \%$.

Keyword: Inchinerator, Biomass, ash.

\section{PENDAHULUAN}

Klinik medis maupun Pusat pelayanan Kesehatan Masyarakat sejak dulu sampai sekarang adalah sebagai ujung tombak pelayanan kesehatan di masyarakat, karena Fasilitas pelayanan kesehatan tersebut langsung bersentuhan dengan masyarakat terutama di pedesaan atau masyarakat ekonomi menengah ke bawah. Bentuk pelayanan itu dapat penanganan langsung kepada pasien atau dalam tahap membuka wacana kesadaran masyarakat akan pentingnya kesehatan lingkungan. Namun aktivitas pusat layanan kesehatan kadang memunculkan persoalan baru. Sering kali Puskesmas kurang memperhatikan masalah penanganan limbah klinis yang biasanya terdiri dari bekas kain kasa, kapas, plastik, jarum suntik dan botol infus. Apalagi sekarang telah banyak Puskesmas dan klinik kesehatan swasta yang membuka layanan rawat inap dan tentu saja limbah klinis yang dihasilkan juga bertambah. Padahal limbah klinis sangatlah berbahaya karena mengandung berbagai macam jenis penyakit dan racun. Limbah klinis ini bila tidak ditangani secara baik dan benar maka fungsi atau peran dari puskesmas atau klinik kesehatan sebagai pembawa kehidupan sehat bagi masyarakat justru akan terbalik (Leonita B, 2014).

Salah satu metode untuk mengurangi kadar pencemaran udara akibat sulfur dan logam berat dapat menggunakan bahan bakar alternative non fosil yaitu berupa biomasa. Biomasa jenis serbuk kayu, sekam padi, tempurung kelapa maupun kulit biji kopi belum dimanfaatkan dengan baik dan hanya menambah tumpukan sampah dan kemudian dibakar ditempat terbuka yang berpotensi menimbulkan pencemaran udara.

Berdasarkan hal tersebut diatas penelitian yang akan dilaksakan adalah dengan membuat prototype isinerator bio massa. Bahan bakar yang akan digunakan merupakan biomasa yang tersedia, murah dan mudah didapatkan disekitar kita. Pengendalian pencemaran udara pada incinerator ini menggunakan technology After Burner yang berlaku sebagai Second Chamber, sedangkan untuk pengendalian pencemaran udaranya menggunakan Technology Wet Scrubber dengan solvent air.

\section{METODELOGI PENELITAIM}

\section{Desain Penelitian}

Penelitian ini bertujuan untuk membuat prototype alat incinerator biomassa yang dapat digunakan dalam pengolahan limbah medis. Adapun jenis penelitian ini adalah bersifat eksperimen. Metode penelitian ekperimen diartikan sebagai metode penelitian yang digunakan untuk mencari pengaruh perlakuan tertentu terhadap yang lain dalam kondisi yang terkendali. Penelitian ini bertujuan untuk menganalisis pengaruh jenis Biomassa yang digunakan dalam proses pembakaran limbah medis B3. Adapun faktor yang diamati dalam penelitian ini adalah jumlah abu jatuh seta mengamati jenis biomasa yang menghasilkan peningkatan suhu yang tertinggi. Gas emisi dalam penelitian ini dikendalikan dengan menggunakan 2 metode yaitu dengan tekhnologi after burner dan metode wet 
scrubber.

\section{VARIABEL PENELITIAN}

Variabel dalam penelitian ini terdiri dari 2 bagian yaitu variabel bebas, variabel terkait dan variabel kontrol. Massing masing variabel akan dijelaskan sebagai berikut:

\section{Variabel Bebas}

Variabel bebas adalah variabel yang akan mempengaruhi hasil dari variabel terkait. Variabel bebas dalam penelitian ini adalah jenis biomassa yang digunakan dalam proses pembakaran limbah medis

\section{Variabel Terkait}

Variabel terkait dalam penelitian ini adalah variabel yang dipengaruhi oleh variabel bebas yaitu jumlah abu, pengingkatan suhu,gas emsisi yang dihasilkan dari berbagai macam biomassa.

\section{Variabel Tetap}

Variable tetap dalam penelitian ini adalah jumlah sampah dan jumlah bahan bakar biomasa 'yang dihitung dalam satuan Kilogram (Kg).

\section{HASIL PENELITIAN}

Penelitian ini menggunakan 3 jenis biomasa sebagai bahan bakar yaitu tempurung kelapa, sekam padai dan tatal kayu. Adapun yang menjadi beban limbah dalam penelitian ini adalah limbah infeksius yang berupa bekas kasa/pembalut, handscund, botol infuse, selang infuse, specimen darah, botol vaksin, kapas dan lainnya. Dari hasil pembakaran didapatkan data sebagai berikut:
Tabel. 1. Hasil Penelitian

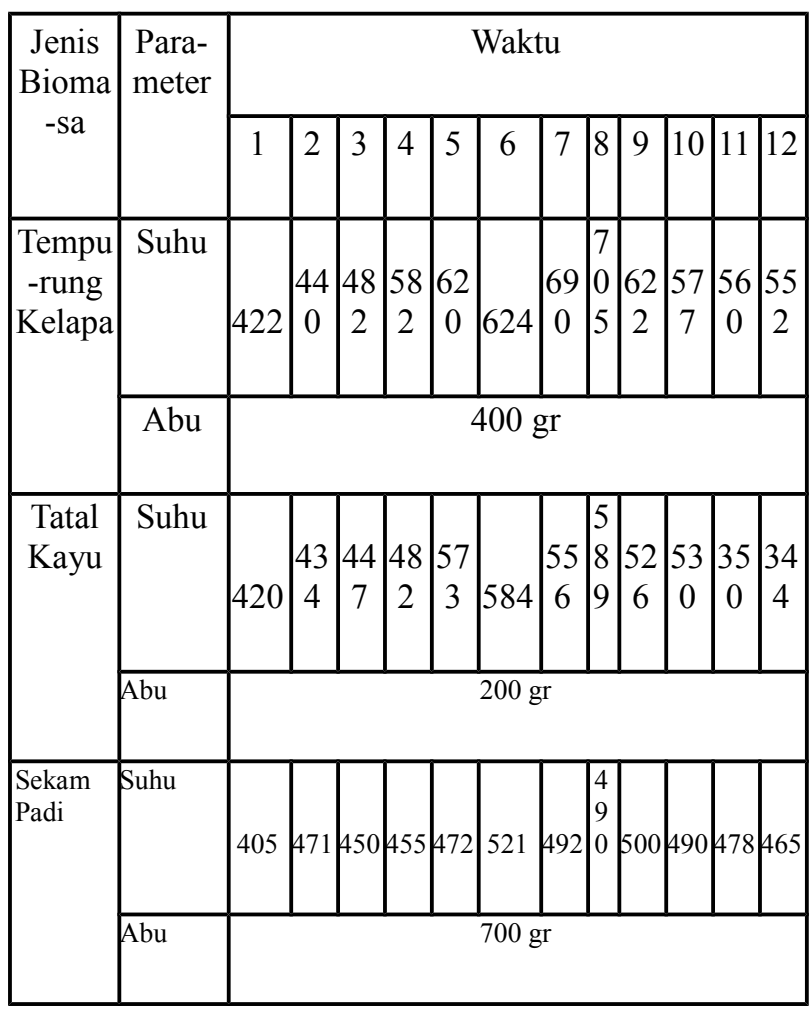

\section{PEMBAHASAN}

\section{Suhu}

Berdasarkan grafik diatas dapat kita ketahui bahwa pencapaian suhu tertinggi terjadi pada jenis biomasa tempurung kelapa dengan suhu puncaknya adalah $705{ }^{\circ} \mathrm{C}$. Sedangkan biomasa tatal memiliki suhu puncaknya pada menit ke 50 dengan suhu puncak $624{ }^{\circ} \mathrm{C}$. Sedangkan pada biomasa sekam padi memiliki suhu puncak pada 521 ${ }^{\circ} \mathrm{C}$.

Pencapaian suhu tertinggi diraih oleh jenis biomassa tempurung kelapa dengan pencapaian suhu puncak sebesar $705{ }^{\circ} \mathrm{C}$. hal serupa ditunjukkan oleh penelitian yang dilakukan oleh nurhilal yang mengukur nilai kalor dari tempurung kelapa dan didapatkan hasil sebesar 6.828 calori/gr. Hasil pengukuran nilai kalori pada tempurung kelapa memiliki nilai yang lebih besar dibandingkan dengan biomassa lainya, sehingga ada kecenderungan bahwa semakin tinggi nilai kalornya maka semakin tinggi 
pula panas yang dihasilkan dalam proses pembakaran.

\section{Pengabuan}

Berdasarkan table diatas dapat diketahui bahwa jenis biomasa yang memiliki reduksi tertinggi yaitu pada biomasa tatal kayu/serbuk gergaji. Sedangkan sekam padi memiliki efiensi reduksi hanya $93 \%$ dan tempurung kelapa memiliki efesiensi reduski sebesar 96 $\%$. Penurunan efesinsi pada tempurung kelapa yang hanya $96 \%$ ini dikarenakan masih banyak terdapat bagian dari carbon tempurung kelapa yang belum sempurna terbakar sehingga menyisakan carbon padat dalam jumlah besar. Permasalahan ini sebenarnya dapat diatasi dengan membakar kembali sisia carbon padat yang belum selesai terbakar setelah memalui proses pengayakan atau proses sortasi lainya. Hal ini sejalan dengan penelitian yang dilakasanalkan oleh Nurhilal yang meneliti tentang pengaruh komposisi campuran sabut dan tempurung kelapa terhadap nilai kalor biobriket dengan perekat molase. Dalam penelitiannya didapakan hasil bahwa sisa abu pembakaran hanya $2,37 \%$ atau memiliki nilai efesiensi reduksi sebesar 97,63\%. Sehingga hasil yang didapat oleh peneliti hamper serupa dengan yang diteliti oleh nurhilal.

\section{KESIMPULAN}

1. Pencapaian suhu tertinggi didapat pada jenis biomasa tempurung kelapa yaitu didapatkan suhu puncak $705{ }^{\circ} \mathrm{C}$.

2. Efesiensi reduksi/penghancuran tertinggi didapatkan pada variable jenis biomassa tatal kayu/ serbuk gergaji dengan efesiensi penyisihan mencapai $98 \%$.

\section{DAFTAR PUSTKA}

Budiman, Arif. 2001. Modifikasi Desain dan Uji Untuk Kerja Alat Pembakar Sampah (incinerator) Tipe Batch. http://repository.ipb.ac.id/handle/123456 [Diakses Februari 2018]
Christian, Hans. 2008. Modifikasi Sistem Burner. http://lontar.ui.ac.id/file?file Digital/125414-

R020854.Pendahuluan.pdf [Diakses Febuari 2018]

Depkes, RI, Kebijakan Kesehatan Lingkungan Dalam Pengelolaan Limbah Media di Fasilitas Pelayanan Kesehatan, (Jakarta; Ditjen PP \& PL, 2011)

Depkes, RI, Pedoman Pelaksanaan Pengelolaan Limbah Padat dan Limbah Cair di

Rumah Sakit. (Jakarta : Direktorat Jenderal PPM \& PPL dan Direktorat Jenderal Pelayanan Medik, 2006)

E.Daubert, Thomas. 1985. Chemical Engineering Thermodynamics. Singapore : Introduction Cataloging in Publication

Hougen, O.A., Kenneth M.W., and Roland A.R. 1954. Chemical Process Principles. Japan : Modern Asia Edition

Kepala Badan Pengendalian Dampak Lingkungan. 1995. Persyaratan Teknis Pengolahan Limbah Bahan Berbahaya dan Beracun. http:mnlh.go.id /pdf/ind/IND-PUU-7-1995 Lampiran Kepka No.2003 Tahun 1995.pdf [diakses Febuari 2018]

Latief, A. Sutowo. Manfaat dan Dampak Penggunaan Insinerator Terhadap Lingkungan.

http://www.polines.ac.id/teknis/upload/ju rnal/jurnal teknis 1336471916.pdf [diakses Febuari 2018]

Leonard S, Jahn dan Welly. 2013. Evaluasi Fungsi Insinerator dalam memusnahkan Limbah B3 di Rumah Sakit TNI Dr. Ramelan

Surabaya.http://ejurnal.its.ac.id/index.ph p/teknik/article/view/4331 [Diakses Febuari 2018]

Marosin, Riyanto dan Ahsonul. 2004. Karakteristik Emisi Gas Buang Insinerator Medis Di Rumah Sakit Jiwa Dadi Makassar Sulawesi Selatan. http://portalgaruda.org/download/article. php?article $=62195 \quad \& \quad \mathrm{val}=456112$ [diakses Febuari 2018]

Pradipta, Adia Nuraga Galih. 2011. Desain 
dan Uji Kinerja Alat Pembakar Sampah (Incinerator) Tipe Batch Untuk Perkotaan Dilengkapi Dengan Pemanas Air. http://repository.ipb.ac.id/handle/123456 789/53003 [Diakses Februari 2018]

Parayitno dan Sukosrono. 2007. Reduksi Limbah Padat Dengan Sistem Pembakaran Dalam Tungku Ruang Bakar. http://digilib.batan.go.id/ ppin/katalog/index.../0216-3128-2007- [diakses Febuari 2018]

Ruslinda, Yenni. 2010. Transformasi Thermal. http://ilearn.unand.ac.id/ ../Teknik \%20Pengolahan\%20Sampah\%204.pdf [diakses Febuari 2018]

Smith. J.M., and Vanness H.C. 1916. Introduction To Chemical Engineering Thermodynamics. Singapore : Cataloging in Publication

Tanikaya. 2011. Proposal Teknologi Pengolahan Limbah Medis Ataupun Non Medis. http://tanikaya.com/index.php? option $=$ comdocman\&task $=$ pdf $\quad$ [diakses Maret 2018]

Wuryani, Sri. 1995. Perpindahan Panas. Pusat Pengembangan Pendidikan Politeknik : Bandung. 